\title{
Impact of Electronic Banking Services on Bank Transactions
}

\author{
Najah Hassan Salamah ${ }^{1}$ \\ ${ }^{1}$ Department of Marketing, Faculty of Economic and Administration, King Abdul-Aziz University, Saudi Arabia \\ Correspondence: Najah Hassan Salamah, Assistant Professor, Department of Marketing, Faculty of Economic and \\ Administration, King Abdul-Aziz University, Saudi Arabia. E-mail: nsalamah@kau.edu.sa, almdnm@yahoo.com
}

Received: November 30, 2016

doi:10.5539/ijef.v9n2p111
Accepted: December 28, 2016 Online Published: January 10, 2017

URL: http://dx.doi.org/10.5539/ijef.v9n2p111

\begin{abstract}
The objective of the research was to evaluate the significance of electronic system integrated in the banking sector for providing convenience services to their clients and the overall impact caused by electronic services on bank transaction. The research has applied analytical descriptive methodology to analyze the impact of electronic banking services on the bank transactions. The total sample size taken for the study was 150 and the questionnaires were distributed among the clients and bank officials to collect the data. The analysis revealed that electronic services have contributed to increase both the financial activity of the bank as well as number of its clients. In the banking sector, professional training can be given to banking officials, so that they can effectively work on the electronic system. The satisfaction has covertly impact a customer inclination towards electronic banking and electronic banking has positively influenced the banking transaction.
\end{abstract}

Keywords: electronic system, service, officials, clients, transaction

\section{Introduction}

\subsection{Introduction to the Problem}

Since the inception, banks have passed through a number of stages and have witnessed many developments in diverse fields. These developments included administrative fields, where services are rendered by these banks to their clients, whether in provision of service aspects, presenting of finance or giving of loans. It benefited the banks with number of advantages that made many people choose to deal with them for managing their funds and investments. Furthermore, the fierce competition among the banks compelled many banks to route for creation and development for achieving competency in businesses activities transactions so, as to gain a large possible number of clients. To improve the management and position of a bank, electronic banking would ply significant role and reduces the cost of operations (Ben-Jadeed \& Molina, 2004, pp. 90-106). Additionally, a research reported that the customer perception of service is greatly impacted by the level of convenience they found in the service they encounter (Bahia \& Nantel, 2000, pp. 84-91). Moreover, the regulation of technology to an extent has provided security in various profession likewise in financial sectors also has incorporated system to reduce threats and chances of manipulation (Rose \& Hudgins, 2006).

As a result of the huge developments in technology, the electronic banking services have emerged with a view of securing competency and quality in transactions (Ito, Hiroya, \& Hitachi, 2000). Since, Internet has become a possession of all people, the big banks have entered internet usage into its systems and commenced to use and present it to their clients to attract more clients. A research study examined that clients can be encouraged by integrating the electronic system and build customer relationship (Rexha, Kingshott, \& Shang, 2003, pp. 53-67). There are many processes in banks that required electronic systems for making the processes effective and reduce the level of work manually performed by the employees or personnel. Moreover, the engagement of customer in transaction is greatly influenced by the electronic systems in banks, where they get the access to perform transaction (Hoffman, Pare Jr, \& Lee, 2002).

\subsection{Merits of Using Internet in Bank Accounts}

There is a general agreement that electronic banks achieve a number of merits for their clients and the following are the most significant ones:

- To make financial services available to clients for 24 hours a day.

- To present latest information or data to clients about their accounts. 
- To help clients obtain required services via Internet and receive financial advice from the bank.

In addition to the above merits, these banks save for the individuals (clients) the time they need to take to go personally to bank sites. Astonishingly, the client can go to the bank dealing with by mere pressing a particular button (Gerrard \& Barton, 2003, pp. 16-28). These services include for example presentation of projects that secure for clients huge profits as well as many other similar services (Al-Janbeehi, 2005).

\subsection{Objectives}

The paper consisted of the following objectives:

1) To project the significance of the electronic banking system in a manner that serves the objectives of both banks and clients.

2) To highlight the significant advantages rendered by banks via the electronic services for clients.

3) To shed light on the distinctive experiment of certain Saudi banks such as Saudi Credit Bank, Saudi American Bank, Riyadh Bank and Arab National Bank regarding the electronic services as well as to know the impact of the electronic services in the efficiency and good quality of transactions, satisfaction of clients and reduction of work pressure on the employees.

\subsection{Problem Statement}

The problem of this research paper is to investigate the impact of electronic services rendered by the Saudi banks in the fields of quality and efficiency that is pertinent to the work provided by these banks to clients as well as the extent to which clients are satisfied with services and impact of electronic services on the smooth running of the work as perceived by the officials of these banks.

\subsection{Research Questions}

Below are the mentioned questions of the research paper:

1) To what extent do electronic services affect the efficiency and quality of the services rendered by the Saudi banks?

2) To what extent do electronic services rendered by Saudi banks affect the satisfaction of clients?

3) To what extent do electronic services rendered by Saudi banks reduce work pressures for officials?

\subsection{Assumption}

The first assumption is the usage of electronic services by Saudi banks leads to quality and efficiency of the services provided to the clients along with satisfaction to clients. Moreover, electronic services also lead to an increase in the percentage of clients. Additionally, another assumption is a reduction in the work pressure of bank officials is also obtained from the usage of electronic services by Saudi Banks.

\section{Method}

The study has relied on the analytical descriptive methodology for achieving the limited objectives of the research. This methodology aims to analyze and describe the problem in question as well as extract its various aspects and dimensions and the extent of its impact on the level of bank services. The data sources, which are represented in primary and secondary sources (ones), comprised the following:

\subsection{Theoretical Study}

Regarding the secondary data obtained by the female researcher was from reading of academic books, periodicals, proceedings as well as recommendations of symposiums, seminar and relevant reports, in addition to certain previous academic dissertations, research papers and studies as well as other sources.

\subsection{Means}

For collecting primary data, questionnaire technique was employed for obtaining primary data and for testing assumptions. In the design of the questionnaire, preciseness and relation between the problem, objectives and assumptions were carefully taken into account.

\subsection{Applied Studies}

Regarding the applied studies, the researcher has depended on the data collected via questionnaire, which was distributed among the sample members to know their opinion concerning the impact of electronic services on bank services. 


\subsection{Population and Sample}

The population comprises of certain clients of the Saudi banks as well as some bank officials, who occupy various occupations. Since, the population is very large, the researcher applied sample to be random one as, this will represent faithfully the original population.

\section{Limits \& Dimensions}

The research was applied during 1436H (2015AD). The geographical dimension was applied in Jeddah Province, because the female researcher is resident of the city of Jeddah and it was easy to move to different sites of the members' sample, visit personally their respective work places and obtain effective results.

Human dimension represents those who are in charge of the electronic services in certain Saudi banks via taking their views about the experiment of their banks in the field of electronic services. It also covers a random sample of the clients of the Saudi banks to know their personal views or perspectives regarding the question of the electronic services rendered by the bank and the benefit that is gained by the bank, the officials for adopting the policy of electronic services.

The female researcher has designed (2) questionnaires. The objective of the first questionnaire was to know the extent of the efficiency of the electronic services of the Saudi banks as well as to measure the extent of satisfaction of clients over such provided electronic services. Moreover, the objective of the second questionnaire was to know the extent of work efficiency through the employment of electronic services from the perspective of certain officials of the Saudi banks as well as to know the extent of the impact of application of electronic services in alleviating the work pressure on the bank officials.

\section{Results}

The copies of the two questionnaires were distributed over certain officials of the Saudi banks as well as over some clients of these banks. After return and examination of questionnaires, it has become evident that there were (150) questionnaires, which were useful for study. However, the female researcher has excluded certain number of questionnaires due to incomplete answers. The (150) questionnaires that were useful for study have been divided as follows:

1) (110) Questionnaires for bank clients officials.

2) (40) Questionnaires for bank officials.

The 5-grade likert scale was used in the design of these questionnaires.

\subsection{Analysis of the First Assumptions}

In the first assumption, the researcher assumed that the usage of electronic services by the Saudi banks leads to the efficiency and quality of the services provided to clients, increment of the percentage of clients and increasing their satisfaction over the services provided by the bank. To verify the correctness of this assumption, I have carried out the analysis for the expressions forming the assumption for both the clients and officials. The results are as follows:

Table 1. Attitude of sample (bank clients) towards the expressions of the first assumption

\begin{tabular}{|c|c|c|c|c|c|}
\hline Expression & I strongly agree & I agree & I am neutral & I don't agree & I strongly don't agree \\
\hline & Percentage & Percentage & Percentage & Percentage & Percentage \\
\hline $\begin{array}{l}\text { The usage of electronics services } \\
\text { contributes to the reduction of the } \\
\text { percentage of mistakes in work }\end{array}$ & 16.7 & 3.3 & 1.7 & 3.3 & 0 \\
\hline $\begin{array}{l}\text { The electronic services contributed to the } \\
\text { national economy }\end{array}$ & 15.0 & 6.7 & 3.3 & 0.0 & 0 \\
\hline $\begin{array}{l}\text { Conduct of financial transaction at the } \\
\text { bank is done through the network of the } \\
\text { electronic services }\end{array}$ & 13.3 & 5.0 & 5.0 & 1.7 & 0 \\
\hline $\begin{array}{l}\text { The electronic dealing at the bank is easy } \\
\text { and rapid advanced and highly efficient }\end{array}$ & 20.0 & 1.7 & 1.7 & 0.0 & 1.6 \\
\hline Total & 60 & 16.7 & 11.67 & 5.0 & 1,6 \\
\hline
\end{tabular}

From the above Table 1, it is remarked that there is a high degree of agreement over the expressions that constitute the first assumption by the category of clients. The percentage of that agreement was $(65 \%)$ of the total responses forming up the assumption. This attitude is supported by the agreement response, which were 
(16.7). From the answer with (I am neutral), whose percentage was (11.7\%), and it is observed that this confirms the correctness of the first assumption. This indicates the following:

1) The usage of electronic services in the Saudi banks contributed to the reduction in the percentage of mistakes in work.

2) The electronic services contributed to the economy.

3) The procedures of financial transactions in the banks via the Network of the electronic services are preferred.

4) The electronic dealings in the bank is easy, rapid, advanced and with high efficiency.

Table 2. Attitude of sample (bank officials) towards the expressions of the first assumption

\begin{tabular}{lccccc}
\hline Expression & I strongly agree & I agree & I am neutral & I don't agree I strongly don't agree \\
\cline { 2 - 5 } & Percentage & Percentage & Percentage & Percentage & Percentage \\
\hline $\begin{array}{l}\text { The electronics services contributed to the } \\
\text { increase of the financial activity at the bank. }\end{array}$ & 16.3 & 4.3 & 3.3 & 1.1 & 0.0 \\
$\begin{array}{l}\text { The electronic services contributed to the } \\
\text { increase of the number of the bank clients }\end{array}$ & 21.7 & 1.1 & 1.1 & 0.0 & 1.1 \\
$\begin{array}{l}\text { The usage of electronic services attracted a } \\
\text { number of clients to the Saudi banks. }\end{array}$ & 18.5 & 2.2 & 1.1 & 2.2 & 1.1 \\
$\begin{array}{l}\text { The electronic services contributed to the } \\
\text { increase of quality of work presented by the } \\
\text { bank }\end{array}$ & 18.5 & 2.2 & 1.1 & 2.2 & 1.1 \\
Total & 75 & 9.8 & 6.5 & 5.4 & 3.3 \\
\hline
\end{tabular}

The above Table 2, displays the response of the sample members (officials of Saudi banks) towards the expressions of the first assumption, which stipulates that the usage of the Saudi banks for electronic services system leads to efficiency of services offered to clients, increase the percentage of clients and their satisfaction over the services provided by the bank. The percentage of those who responded to the expressions of the assumption with (I strongly agree) was (75\%) of the total responses. This attitude is supported by the agreement response, which was (9.8), followed by that (percentage) of those who answered with (I am neutral), which was (6.5). However, the response of those who said (I strongly do not agree) or (I do not agree) was small and quite insignificant. This indicates the following:

1) The electronics services contributed to the increase of the financial activity at the bank.

2) The electronic services contributed to the increase of the number of the bank clients.

3) The usage of electronic services attracted a number of clients to the Saudi banks.

4) The electronic services contributed to the increase of quality of work presented by the bank.

This indicates that the usage of the Saudi banks for electronic services system contributed to the efficiency of services offered to clients; increase the percentage of clients and their satisfaction over the services provided by the bank. Thus, the results of the first assumption were correct as indicated by both the two categories; the officials of the Saudi banks and the clients of the Saudi banks.

Table 3. Attitude of sample (bank officials) towards the first expression of the first assumption

\begin{tabular}{llllll}
\hline Expression & I strongly agree & I agree & I am neutral & I don't agree & I strongly don't agree \\
\cline { 2 - 5 } & Percentage & Percentage & Percentage & Percentage & Percentage \\
\hline $\begin{array}{l}\text { The usage of the electronics services } \\
\text { contributed to the increase of the level of }\end{array}$ & 24.4 & 4.4 & 2.2 & 2.2 & 0.0 \\
services. \\
$\begin{array}{l}\text { The electronic services contributed to the } 17.8 \\
\text { increase of the satisfaction of clients over the } \\
\text { services offered by the bank. }\end{array}$ \\
$\begin{array}{l}\text { The electronic services contributed in } \\
\text { securing an opportunity for clients to easily } \\
\text { complete transactions, an act that increased } \\
\text { the satisfaction of the clients of those banks. }\end{array}$ \\
\begin{tabular}{l} 
Total \\
\hline
\end{tabular}
\end{tabular}


Through the above expressions, which represent Table 3, the researcher has sought to know the extent to which clients achieve a degree of satisfaction as a result of using electronic services. All the expressions were presented to the sample, which represent client's category.

The percentage of those who responded to the expressions of the assumption with (I strongly agree) was (68.9\%) of the total responses. This attitude is supported by the agreement response, which were (15.6). However, the percentage of the response of those who said (I am neutral) was (11.11\%). As regards the attitude rejecting the expressions of the assumption found that the percentage of those who responded with (I strongly do not agree) was (2.2) and that of those who responded with (I do not agree) was also (2.2\%), and this percentage is very small. This is evidence that the second expression of the assumption is correct, especially in connection to the fact that it confirmed the achievement of the satisfaction of clients as a result of electronic services provided by the Saudi banks. This indicates the following:

1) The usage of the electronics services contributed to the increase of the level of services.

2) The electronic services contributed to the increase of the satisfaction of clients over the services offered by the bank.

3) The electronic services contributed in securing an opportunity for clients to easily complete transactions, an act that increased the satisfaction of the clients of those banks.

\subsection{Analysis of the Second Assumption}

In the second assumption, the researcher has assumed that the usage of electronic services by the Saudi banks leads to the reduction of work pressure on the officials of the banks. To verify the correctness of this assumption, the researcher has formulated a number of expressions that she addressed to the officials of the Saudi banks. The response of the sample members for the expressions composing the assumption were as bellow in this Table 4:

Table 4. Attitude of sample (bank officials) towards the expressions of the second assumption

\begin{tabular}{|c|c|c|c|c|c|c|}
\hline \multirow[t]{2}{*}{ Expression } & I strongly agree & I agree & I am neutral & I don't agree & I strongly don't agree & \\
\hline & Percentage & Percentage & Percentage & Percentage & Percentage & \\
\hline $\begin{array}{l}\text { The electronics services contributed to the } \\
\text { reduction of the percentage of the transactions that } \\
\text { are undertaken by the official daily (or during any } \\
\text { work day) }\end{array}$ & 21.7 & 1.1 & 1.1 & 1.1 & 0.0 & \\
\hline $\begin{array}{l}\text { The electronic services contributed to the reduction } \\
\text { of the reception of the financial transactions that } \\
\text { pertain to the payment of bills such as bills of } \\
\text { electricity, water supply or mobile etc, which were } \\
\text { paid in the past by cashiers. }\end{array}$ & 25.0 & 0.0 & 0.0 & 0.0 & 0.0 & \\
\hline $\begin{array}{l}\text { The electronic services contributed to the reduction } \\
\text { of the cash deposits and withdrawals transactions } \\
\text { performed daily by clients. }\end{array}$ & 20.7 & 2.2 & 2.2 & 1.1 & 0.0 & \\
\hline $\begin{array}{l}\text { The electronic services contributed to alleviating } \\
\text { the burden of work for officials of the banks as } \\
\text { work discharge is undertaken electronically at the } \\
\text { end of each work day. }\end{array}$ & 19.6 & 1.1 & 1.1 & 1.1 & 1.1 & \\
\hline Total & 87 & 4.3 & 4.3 & 3.3 & 1.1 & 100 \\
\hline
\end{tabular}

The above Table 4 shows the opinions of the sample members (bank officials) towards the expressions forming the second assumptions.

The percentage of those who responded to the expressions of the assumption with (I strongly agree) was (87\%) of the total responses. We notice here that the agreement percentage for the expression was very high. This attitude is supported by the agreement response (I agree) which was (4.3\%), and it equalized with that (percentage) of those who answered with (I am neutral). However, the percentage of the response of those who said (I do not agree) was (3.3\%) and that (percentage) of those who said (I strongly do not agree) was only $(1.1 \%)$. This indicates that the second assumption of the study is correct; and that the usage of electronic services at work has contributed to the reduction of work pressures suffered by bank officials. The above confirms the following:

1) The electronics services contributed to the reduction of the percentage of the transactions that are 
undertaken by the official daily (or during any work day).

2) The electronic services contributed to the reduction of the reception of the financial transactions that pertain to the payment of bills such as bills of electricity, water supply or mobile etc., which were paid in the past by cashiers.

3) The electronic services contributed to the reduction of the cash deposits and withdrawals transactions performed daily by clients.

4) The electronic services contributed to alleviating the burden of work for officials of the banks as work discharge is undertaken electronically at the end of each work day.

Table 5. Personal data of the female bank clients

\begin{tabular}{ll}
\hline Statement & Percentage \\
\hline 18 and less than 30 years & $10 \%$ \\
30 and less than 40 years & $20 \%$ \\
40 and less than 50 years & $60 \%$ \\
50 and more years & $10 \%$ \\
Total & $100 \%$ \\
\hline
\end{tabular}

From the above Table 5, it is conspicuous that the age bracket of $60 \%$ of the total female members of the sample is between 40 and 50 years; and that the age bracket of $20 \%$ of them is less than 40 years, followed by $10 \%$ for those whose age is either less than 30 years or above 50 years. This indicates that $60 \%$ of the sample belongs to the age bracket between 40 to less than 40 and the responses of those members are objective.

Table 6. Personal data of the female bank clients

\begin{tabular}{ll}
\hline Statement & Percentage \\
\hline Secondary education & $30 \%$ \\
University Education & $50 \%$ \\
Postgraduate Education & $20 \%$ \\
Total & $100 \%$ \\
\hline
\end{tabular}

From the above table 6 , it is clear that $50 \%$ of the total female members of the sample hold university education certificates, and this is followed by that holding secondary education certificate with $30 \%$, followed by those having postgraduate university certificates with $20 \%$. This indicates that $70 \%$ of the sample members hold university education certificates $(50 \%$ hold university education degrees and $20 \%$ postgraduate education degrees).

Table 7. Occupation

\begin{tabular}{lcc}
\hline Statement & Frequency & Percentage \\
\hline Housewives & 6 & $20 \%$ \\
officials & 6 & $20 \%$ \\
Businesswomen & 18 & $60 \%$ \\
Total & 30 & $100 \%$ \\
\hline
\end{tabular}

From the above Table 7, it is conspicuous that the distribution of the questionnaire was according to the occupations of the sample members was that $60 \%$ of the sample members practices the occupations of businesswomen, and this was followed by $20 \%$ working as officials and an equal $20 \%$ with the occupations of housewives. This indicates that $60 \%$ of the sample was businesswomen, who are visit banks more frequently; and that they benefit more than other women practicing different occupations in the usage of Internet for bank transactions.

Table 8. Monthly income (salary)

\begin{tabular}{ll}
\hline Statement & Percentage \\
\hline Less than 3000 S R & $20 \%$ \\
Between (3000-9000) S R & $50 \%$ \\
More than 9000 S R & $30 \%$ \\
Total & $100 \%$ \\
\hline
\end{tabular}


From the above Table 8, it is clear that the age bracket of $50 \%$ of the total female members of the sample receive a monthly salaries between (3000-9000), and this is followed by $30 \%$ of the sample whose monthly salaries were than 9000 and more, and this was followed lastly by $20 \%$ of sample members receiving monthly salaries less 3000 Saudi Riyals.

Table 9. Personal data of the female bank officials

\begin{tabular}{lc}
\hline Statement & Percentage \\
\hline 18 and less than 30 years & $20 \%$ \\
30 and less than 40 years & $40 \%$ \\
40 and less than 50 years & $30 \%$ \\
50 and more years & $10 \%$ \\
Total & $100 \%$ \\
\hline
\end{tabular}

From the above Table 9, it is conspicuous that the age bracket of $60 \%$ of the total female members of the sample is between 30 and 50 years; and that the age bracket of $20 \%$ of them is less than 30 years, followed by $10 \%$ for those whose age is either less than 30 years ,and $10 \%$ above 50 years. This indicates that $70 \%$ of the sample belongs to the age bracket between 30 to less than 50 and the responses of those members are objective.

Table 10. Educational qualification

\begin{tabular}{lc}
\hline Statement & Percentage \\
\hline Secondary education & $2 \%$ \\
University Education & $79 \%$ \\
Postgraduate Education & $19 \%$ \\
Total & $100 \%$ \\
\hline
\end{tabular}

From the above Table 10, it is clear that $79 \%$ of the total female bank officials of the sample hold university education certificates, and this is followed by those holding postgraduate education certificate with $19 \%$, followed by those having secondary education certificates with $2 \%$. This indicates that $98 \%$ of the sample female bank officials hold university education certificates- (79\% hold university education degrees and $19 \%$ postgraduate education degrees).

Table 11. Monthly Income

\begin{tabular}{lc}
\hline Statement & Percentage \\
\hline Less than 3000 S R & $0 \%$ \\
Between (3000-9000) S R & $76 \%$ \\
More than 9000 S R & $24 \%$ \\
Total & $100 \%$ \\
\hline
\end{tabular}

From the above Table 11, it is clear that the age bracket of $76 \%$ of the total female members of the sample receive a monthly salaries between (3000-9000), and this is followed by $24 \%$ of the sample whose monthly salaries were than 9000 and more, and this was followed by $0 \%$ of sample members receiving monthly salaries less 3000 Saudi Riyals.

Table 12. Year of experience

\begin{tabular}{lc}
\hline Statement & Percentage \\
\hline Less than 5 years & $40 \%$ \\
5 and less than 10 years & $35 \%$ \\
10 years and less 15 years & $20 \%$ \\
15 years and more & $5 \%$ \\
Total & $100 \%$ \\
\hline
\end{tabular}

From the above Table 12, it is conspicuous that the year of experience bracket of $75 \%$ of the total female members of the sample is between Less than 5 years and 10 years; and that the year of experience bracket of $20 \%$ of them is 10 years and less 15 years, followed by $5 \%$ for those whose year of experience is 15 years and more. 
This indicates that $55 \%$ of the sample belongs to the year of experience bracket between 5 to less than 15 years and the responses of those members are objective.

\section{Discussion}

Through the previous analysis of data pertaining to the two assumptions of the study, the female researcher was able to reach a number of results and included that the usage of electronic services in the Saudi banks contributed to the reduction of the percentage of mistakes at work and this leads to achieve competency at work. Additionally, the results indicated that electronic services has contributed to economy of time, because many bank transactions are now performed directly through Automatic Teller Machine (ATM). It was found that the bank clients preferred the conduct of financial transactions in the banks via the network of electronic services. This contributed for achieving quality and efficiency in the services offered by the bank. The electronic form of banking provides the ease to customers as well as officials to get through the process by electronic delivery channel and give certain benefits in terms of satisfaction, loyalty, and convenient usage (Aladwani, 2001, pp. 213-225).

A study stated major's problems in the traditional banking systems, which leads to waste of time, pending transfer of money, people waiting in queue to be facilitated and errors in collecting and storing the data (ASIA, 2015). As per this problem, banking institutions took the privilege of technology and integrated electronic system in banking services. Furthermore, a reduction in the reception of financial transactions that pertain to payment of various utilities bills as well as cash deposit and withdrawal transactions was also observed (Yousafzai, Pallister, \& Foxall, 2003, pp. 847-860). Also, that the integration of technology in the banking sector has been usefully employed and electronic services have reduced the burden of officials performing accounts auditing as the electronic system does effectively on their behalf. High customer satisfaction would enable long term relationship with their clients that it would build trust towards the services provided by banks. Banks are striving to allocate the transactions from the telephones to the Internet and now from the internet to the different forms of electronic bankings (Cunningham \& Fröschl, 2013; Burton \& Brown, 2014). Bank are in serious competitions with each other and offers their clients with more convenient products with acceptable levels of costs (Agwu \& Carter, 2014).

The integration of electronic system in banks has impacted positively on the bank transaction process and increases the efficiency of rendering convenient services to the employees. Customer satisfaction has also impacted positively and the development of trust has influenced the corporate client's propensity for use the electronic banking system. Therefore, it can be concluded that satisfaction has covertly impact a customer inclination towards electronic banking. The impact that risk might exert on Information Technology adoption has established limited consideration (Martins et al., 2014; Yoon \& Stege, 2013).

The research has attained some important recommendations that entails considering to disseminate the culture of electronic dealing through banking services among clients. It is suggested that proper training should be given to the bank officials on detecting and addressing electronic mistakes as well as giving suitable solutions and remedies for such mistakes. Moreover, to urge those concerned to participate in symposiums and workshops that seek to achieve competency in modern technologies that focus on electronic bank services. It is also recommended that number of field studies and researches should be conducted to know the opinions of clients on electronic services needed by the Saudi banks.

\section{Acknowledgments}

The author is very thankful to all the associated personnel in any reference that contributed in/for the purpose of this research. Further, this research holds no conflict of interest and is not funded through any source.

\section{References}

Agwu, M. E., \& Carter, A. L. (2014). Mobile phone banking in Nigeria: Benefits, problems and prospects. International Journal of Business and Commerce, 3(6), 50-70.

Aladwani, A. M. (2001). Online banking: a field study of drivers, development challenges, and expectations. $\begin{array}{llll}\text { International Journal of Information } & \text { Management, 213-225. }\end{array}$ http://dx.doi.org/10.1016/S0268-4012(01)00011-1

ASIA, N. M. (2015). Electronic Banking and Financial Performance of Commercial Banks in Rwanda: A Case Study of Bank of Kigali (Doctoral dissertation, Jomo Kenyatta University of Agriculture and Technology).

Bahia, K., \& Nantel, J. (2000). A reliable and valid measurement scale for the perceived service quality of banks. International Journal of Bank Marketing, 18(2), 84-91. http://dx.doi.org/10.1108/02652320010322994 
Ben-Jadeed, M., \& Molina, A. (2004). The emergence and evolution of e-banking in Saudi Arabia: The case of samba financial group. Frontiers of E-Business Research, 1, 90-106.

Burton, M., \& Brown, B. (2014). The financial system and the economy: Principles of money and banking. Routledge.

Cunningham, P., \& Fröschl, F. (2013). Electronic business revolution: Opportunities and challenges in the 21st century. Springer Science \& Business Media.

Gerrard, P., \& Barton Cunningham, J. (2003). The diffusion of internet banking among Singapore consumers. International journal of bank marketing, 21(1), 16-28. http://dx.doi.org/10.1108/02652320310457776

Hoffman, N., Pare Jr, D. F., \& Lee, J. A. (2002). U.S. Patent No. 6,366,682. Washington, DC: U.S. Patent and Trademark Office.

Ito, A., \& Hiroya, M. (2000). U.S. Patent No. 6,039,250. Washington, DC: U.S. Patent and Trademark Office.

Martins, C., Oliveira, T., \& Popovič, A. (2014). Understanding the Internet banking adoption: A unified theory of acceptance and use of technology and perceived risk application. International Journal of Information Management, 34(1), 1-13. http://dx.doi.org/10.1016/j.ijinfomgt.2013.06.002

Rexha, N., Kingshott, R. P. J., \& Shang, Aw, A. (2003). The impact of the relational plan on adoption of electronic banking. Journal of Services Marketing, 17(1), 53-67. http://dx.doi.org/10.1108/08876040310461273

Rose, P., \& Hudgins, S. (2006). Bank management and financial services. The McGraw- Hill.

Yoon, H. S., \& Steege, L. M. B. (2013). Development of a quantitative model of the impact of customers' personality and perceptions on Internet banking use. Computers in Human Behavior, 29(3), 1133-1141. http://dx.doi.org/10.1016/j.chb.2012.10.005

Yousafzai, S. Y., Pallister, J. G., \& Foxall, G. R. (2003). A proposed model of e-trust for electronic banking. Technovation, 23(11), 847-860. http://dx.doi.org/10.1016/S0166-4972(03)00130-5

\section{Appendix}

\section{Appendix A}

\section{Questionnaire directed to the female clients of the Saudi banks}

Pleas fill in the blank space of this questionnaire you think appropriate to your opinion:

\begin{tabular}{|c|c|c|c|c|c|}
\hline Expression & $\begin{array}{l}\text { I strongly } \\
\text { agree }\end{array}$ & I agree & $\begin{array}{c}\text { I am } \\
\text { neutral }\end{array}$ & $\begin{array}{l}\text { I don't } \\
\text { agree }\end{array}$ & $\begin{array}{l}\text { I strongly } \\
\text { don't agree }\end{array}$ \\
\hline \multicolumn{6}{|l|}{$\begin{array}{l}\text { The usage of electronics services at banks reduces the percentage of } \\
\text { mistakes at work }\end{array}$} \\
\hline \multicolumn{6}{|l|}{ The electronic services have contributed in the economy of time. } \\
\hline \multicolumn{6}{|l|}{$\begin{array}{l}\text { The clients of the bank prefer the conduct of financial transactions at banks } \\
\text { via the network of electronic services. }\end{array}$} \\
\hline \multicolumn{6}{|l|}{ The electronic dealing is easy, rapid and with high efficiency work day. } \\
\hline \multicolumn{6}{|l|}{$\begin{array}{l}\text { The usage of electronics services at banks has contributed to improving the } \\
\text { level of services. }\end{array}$} \\
\hline \multicolumn{6}{|l|}{$\begin{array}{l}\text { The electronics services have contributed to increasing your satisfaction } \\
\text { with the bank. }\end{array}$} \\
\hline $\begin{array}{l}\text { Your ability to complete your financial transactions via electronic services } \\
\text { with ease increased your satisfaction. }\end{array}$ & & & & & \\
\hline
\end{tabular}

Put ( ) against the appropriate expression

Personal data:

(1) Age

- 18 and less than 30 years

- 30 and less than 40

- 40 and less than 50

- 50 years and more 
(2) Educational Level

- Secondary School Certificate

- Bachelor's degree

- Postgraduate Degree

(3) Occupation

- Official

- Businesswoman

- housewife

- Other (Specify--------------)

(4) Monthly Salary

- less than $3000 \mathrm{SR}$

- From 3000 to less than 9000SR

- $\quad$ From 9000 SR and more

\section{Appendix B}

\section{Questionnaire directed to the female officials of the Saudi banks}

Pleas fill in the blank space of this questionnaire you think appropriate to your opinion:

\begin{tabular}{|c|c|c|c|c|c|}
\hline Expression & $\begin{array}{l}\text { I strongly } \\
\text { agree }\end{array}$ & I agree & $\begin{array}{c}\text { I am } \\
\text { neutral }\end{array}$ & $\begin{array}{l}\text { I don't } \\
\text { agree }\end{array}$ & $\begin{array}{l}\text { I strongly } \\
\text { don't agree }\end{array}$ \\
\hline \multicolumn{6}{|l|}{$\begin{array}{l}\text { 1-The electronics services have contributed to the increase of financial activity at } \\
\text { the bank. }\end{array}$} \\
\hline \multicolumn{6}{|l|}{$\begin{array}{l}\text { 2-The electronic services have contributed to increasing the number of clients at } \\
\text { the bank. }\end{array}$} \\
\hline \multicolumn{6}{|l|}{ 3-The electronic services have attracted a number of clients to the bank. } \\
\hline \multicolumn{6}{|l|}{ 4-The electronic service have increased the quality of work offered by the bank. } \\
\hline \multicolumn{6}{|l|}{ 5-The electronics services have contributed to reducing the percentage of the daily } \\
\hline \multicolumn{6}{|l|}{ financial transactionsperformed by the banks. } \\
\hline \multicolumn{6}{|l|}{$\begin{array}{l}\text { 6-The electronics services have contributed to reducing the receipt of financial } \\
\text { transactions pertaining to payment of bills. }\end{array}$} \\
\hline \multicolumn{6}{|l|}{$\begin{array}{l}\text { 7-The electronic services have contributed to reducing cash deposit and } \\
\text { withdrawal transactions. }\end{array}$} \\
\hline $\begin{array}{l}\text { 8-The electronic services have contributed to lessening the burden of account } \\
\text { auditing undertaken by bank officials. }\end{array}$ & & & & & \\
\hline
\end{tabular}

Put ( ) against the appropriate expression

Personal data:

(1) Age

- 18 and less than 30 years

- 30 and less than 40

- 40 and less than 50

- 50 years and more

(2) Educational Level

- Secondary School certificate

- Bachelor's degree

- Postgraduate degree

(3) Monthly salary

- Less than 3000 Saudi Riyals

- From 3000 to less than9000 Saudi Riyals 
- $\quad$ From 9000 Saudi Riyals and more

(4) Year of Experience

- Less than 5 years

- 5 and less than 10 years

- 10 years and less 15 years

- 15 years and more

\section{Copyrights}

Copyright for this article is retained by the author(s), with first publication rights granted to the journal.

This is an open-access article distributed under the terms and conditions of the Creative Commons Attribution license (http://creativecommons.org/licenses/by/4.0/). 